\title{
Critical evaluation of a method for estimating amino acid requirements for maintenance in the rat by measurement of the rate of ${ }^{14} \mathrm{C}$-labelled amino acid oxidation in vivo
}

\author{
By R. J. NEALE* AND J. C. WATERLOW \\ Department of Human Nutrition, London School of Hygiene and \\ Tropical Medicine, Keppel Street, London WC $E_{7} H T$ \\ (Received 28 August 1973-Accepted 16 November 1973)
}

\begin{abstract}
I. The object of the experiments was to estimate the maintenance requirements for lysine and leucine by a radioactive method. Rats were given a single dose of ${ }^{14} \mathrm{C}$-labelled lysine or leucine and groups of animals were killed after 15,20 and $30 \mathrm{~d}$.

2. After $20 \mathrm{~d}$ the specific radioactivity (SR) of protein was approximately the same in liver, muscle and viscera; it was somewhat lower in skin. Once uniform SR is achieved, the rate of loss of radioactivity is a measure of the rate of endogenous loss of the amino acid.

3. The rate of loss between 20 and $30 \mathrm{~d}$ was measured in two ways: from the daily output of expired ${ }^{14} \mathrm{CO}_{2}$, and from the decrease, over the $10 \mathrm{~d}$ interval, of the total amount of radioactivity retained in the body.

4. For the first $x_{5} \mathrm{~d}$ after administration of the labelled amino acid, all rats were given a lowprotein or low-amino acid diet on which body-weight was maintained constant. For the second I $5 \mathrm{~d}$ period some rats were kept on this diet; others were transferred either to a protein-free diet or to a diet lacking the specific amino acid (lysine or leucine) which had been administered in the labelled form.

5. The fractional rate of amino acid loss in the different experiments ranged from $I_{5} \cdot 5$ to $3.5 \% / \mathrm{d}$, being greatest with the protein-free diet. The absolute rates of loss were calculated from measurements of the total lysine and leucine content of rats.

6. The best estimates of the rate of endogenous amino acid loss obtained in this way, expressed as $\mathrm{mg} / \mathrm{kg}^{0.75}$ per $\mathrm{d}$ were: lysine ${ }_{13} 6$, leucine 80 . These estimates are higher than most estimates of maintenance requirements obtained by growth or nitrogen balance methods and possible reasons for these discrepancies are discussed.
\end{abstract}

Amino acid requirements for growth and maintenance have been estimated by growth assays (Neuberger \& Webster, 1945; Rao, Metta \& Johnson, 1959), nitrogenbalance methods (Smith \& Johnson, I967), plasma amino acid levels (Zimmerman $\&$ Scott, 1965) and more recently by radioactive techniques (Brookes, Owens \& Garrigus, 1972). The maintenance requirement alone, however, is more difficult to estimate accurately, especially for lysine and leucine, as growth responses to varying levels of intake are not well defined (Bender, 1961; Said \& Hegsted, 1970). This is not difficult to understand, as recent isotopic studies have shown that these essential amino acids are highly re-utilized for protein synthesis and are also conserved with great efficiency (Garlick, Millward \& Waterlow, 1974).

In the present work another approach to the estimation of maintenance requirement has been attempted by determining the loss of radioactivity from the body after administration of ${ }^{14} \mathrm{C}$-labelled leucine or lysine, under conditions in which adaptive mechanisms should reduce the loss of amino acids to a minimum.

* Present address: Department of Applied Biochemistry and Nutrition, University of Nottingham School of Agriculture, Sutton Bonington, Loughborough LE 2 5RD, Leics. 
Table I. The composition $(\mathrm{g} / \mathrm{kg})$ of the basal, protein-free $(P F)$, lysine-free $(L F)$ and leucine-free diets

$\begin{array}{lcccc} & \begin{array}{c}\text { Basal } \\ \text { (low-protein) }\end{array} & \text { pF } & \text { LF* } & \text { Leucine-freet } \\ \text { Casein } & 45 & - & - & - \\ \text { Arachis oil } & 50 & 50 & 50 & 50 \\ \text { Dextrinized starch } & 300 & 300 & 300 & 300 \\ \text { Maize starch } & 543 & 589 & 546 & 546 \\ \text { Salt mixture } & 50 & 50 & 50 & 50 \\ \text { Vitamin mixturet } & \text { Ir } & \text { II } & \text { II } & \text { I I } \\ \text { DL-methionine } & - & - & 43 & 43 \\ \text { Amino acid mixture§ } & & & & \end{array}$

* Amino acid mixture minus lysine.

$\uparrow$ Amino acid mixture minus leucine.

I Composition as described by Payne \& Stewart (1972).

$\$$ Amino acid mixture contained L-amino acids in the following amounts $(\mathrm{g} / \mathrm{kg}$ diet): arginine $\mathrm{r} \cdot 58$; histidine $\mathrm{I} \cdot 58$; isoleucine $2 \cdot 75$; methionine $\mathrm{r} \cdot 95$; cystine $\mathrm{I} \cdot \mathrm{I} 5$; threonine $2 \cdot 64$; serine $2 \cdot \mathrm{r} 8$; proline $2 \cdot 18$; leucine 4.00 ; phenylalanine 3.48 ; tyrosine $1 \cdot 15$; tryptophan 0.94 ; lysine $4 \cdot 15$; alanine $2 \cdot 18$; aspartic acid 4.20 ; glutamic acid 9.62 ; glycine 1.59 ; valine, 3.48 .

\section{EXPERIMENTAL}

\section{Animals and diets}

All rats were obtained from commercial suppliers, and were housed four to a cage.

In most experiments male black- and white-hooded rats weighing about $100 \mathrm{~g}$ were used, but in Expts $2 \mathrm{~B}$ and $2 \mathrm{C}$ male weanling rats of the Sprague-Dawley strain weighing $35^{-45} \mathrm{~g}$ were used.

All rats were initially given a low- $\mathrm{N}$ diet, which either contained $45 \mathrm{~g}$ casein $/ \mathrm{kg}$ (casein supplied by Unigate Foods Ltd) or an amino acid mixture equivalent to this amount of casein. The composition of these diets is shown in Table I.

Two series of experiments were done. In the first (Expt I) after an initial period on the low-casein diet, the rats were given ${ }^{14} \mathrm{C}$-labelled lysine or leucine by stomach tube. In some rats $\mathrm{CO}_{2}$ was collected for the next $3 \mathrm{~h}$, to determine the initial loss of isotope. All rats were maintained on the low-casein diet, and groups of animals were killed at $3 \mathrm{~h}$, and at $\mathrm{I} 5,20$ and $30 \mathrm{~d}$ after administration of the labelled amino acid.

In the second series of experiments $(2 \mathrm{~A}, \mathrm{~B}$ and $\mathrm{C})$ rats were given labelled lysine (Expts $2 \mathrm{~A}$ and $2 \mathrm{~B}$ ) or leucine (Expt $2 \mathrm{C}$ ) by stomach tube. They were then maintained on one of the basal diets (casein or amino acid mixture) for $\mathrm{I}_{5} \mathrm{~d}$. The diet was then changed to a protein-free (PF) diet or a lysine-free (LF) diet (Expts $2 \mathrm{~A}$ and $2 \mathrm{~B}$ ) or a leucine-free diet (Expt $2 \mathrm{C}$ ) (Table $\mathrm{I}$ ). Respiratory $\mathrm{CO}_{2}$ was collected for 2-3 h almost every day from the time when the diet was changed until day 30 , when the animals were killed. In one experiment ( $2 \mathrm{~A})$ groups of rats were also killed at $20 \mathrm{~d}$.

The purpose of this experimental design was as follows: $(a)$ To estimate the endogenous rate of amino acid loss from isotopic data it is necessary to achieve more or less uniform labelling of the tissue proteins. The results of Expt I showed that this condition was not reached until about $20 \mathrm{~d}$ after administration of the isotope. To measure the rate of loss the animals must be maintained for a further period of at least ro d; $(b)$ we thought it desiable to measure the rate of loss under conditions 
where the intake of the amino acid under consideration was zero. However, to maintain animals on such diets for $30 \mathrm{~d}$ would cause excessive weight loss, even if they survived; $(c)$ we wanted to compare the rate of loss of isotope in $\mathrm{CO}_{2}$ with the rate determined from measurements of radioactivity retained in the body at different times after the dose.

The amino acids used were $\mathrm{L}-\left[\mathrm{U}-{ }^{14} \mathrm{C}\right] \mathrm{lysine}$ and $\mathrm{L}-\left[\mathrm{U}-{ }^{14} \mathrm{C}\right]$ leucine of specific radioactivity ro $\mathrm{mCi} / \mathrm{mmol}$, obtained from the Radiochemical Centre, Amersham. The ${ }^{14} \mathrm{C}$-labelled amino acids were diluted with distilled-water to give a solution containing between 10 and $20 \mu \mathrm{Ci} / \mathrm{ml}$. In Expt 2, carrier amino acid was added to a final concentration of Io mM. In Expt $\mathrm{r}$, carrier was added in some but not all groups of rats. The amino acids were administered by stomach tube; the volume of solution given was $\mathrm{I} \mathrm{ml}$, containing $\mathrm{IO}-20 \mu \mathrm{Ci}$ radioactivity.

\section{Preparation of tissues}

Rats were killed with chloroform and weighed samples of liver, muscle, viscera and skin were homogenized in $5 \mathrm{ml}$ trichloroacetic acid (TCA, $100 \mathrm{~g} / \mathrm{l}$ ) in a groundglass homogenizer. The supernatant fractions were separated by centrifugation. The precipitated protein and the supernatant fraction were then washed as previously described (Neale \& Waterlow, 1974). After removal of these small tissue samples, the whole liver, whole viscera, whole skin and remaining carcass were weighed, digested with $2 \mathrm{M}-\mathrm{KOH}$, the solutions diluted and counted for ${ }^{14} \mathrm{C}$ radioactivity as previously described (Neale \& Waterlow, 1974).

$\mathrm{CO}_{2}$ was collected for a 2 or $3 \mathrm{~h}$ period into one or two $50 \mathrm{ml}$ solutions of $\mathrm{KOH}$ in gas-trapping bottles with sintered-glass bubblers (Quickfit, England). In Expt 2 the total daily loss of ${ }^{14} \mathrm{CO}_{2}$ was calculated by multiplying that lost in 2 or $3 \mathrm{~h}$ by a factor of either $\mathrm{I} 2$ or 8 to give $\mathrm{CO}_{2}$ loss in $24 \mathrm{~h}$, since it was found that collections at night gave the same loss over $2-3 \mathrm{~h}$ as in the day.

In Expt $2 \mathrm{~B}$ urine was collected for periods of $24 \mathrm{~h}$ for the whole $20-30 \mathrm{~d}$ period. Rats were housed in stainless-steel metabolism cages (Associated Crates Ltd, Stockport, Cheshire) for this purpose.

\section{Chemical and radioactive measurements}

The total amount of free plus protein-bound lysine or leucine in the whole body of rats which had been maintained on the low-protein diet for between 20 and $30 \mathrm{~d}$ was measured by combining known volumes of $\mathrm{KOH}$-digested liver, viscera, skin and carcass in proportion to the weights of the organs and adding an equal volume of $12 \mathrm{M}$ $\mathrm{HCl}$. The tube was then sealed and hydrolysis of proteins was completed by heating in an oven at $110^{\circ}$ for $24 \mathrm{~h}$. Total amino acid analysis for leucine and lysine was performed on the $\mathrm{HCl}$-free aqueous extract (Moore \& Stein, 1948) with an automatic amino acid analyser (Mark II, Floor model; Locarte, London).

Other chemical and radioactive measurements were those previously described (Neale \& Waterlow, 1974). 


\section{Calculations}

The rate of loss of radioactivity was calculated in two ways:

(a) From the amount of radioactivity retained in tissues or in the whole body at different times after administration of the isotope. It is assumed, as a first approximation, that the radioactivity disappears exponentially. Then the fractional daily rate of loss, $k$, is given by the expression:

$$
\frac{R_{t_{2}}}{R_{t_{1}}}=e^{-k\left(t_{2}-t_{1}\right)}
$$

where $R_{t}$ is the amount of radioactivity recovered at any time $t$ (d).

For the period from day 20 to day 30 after the radioactive dose, virtually the same result is given by the simple arithmetic calculation, in which the loss of isotope is divided by the mean amount of isotope remaining:

$$
k^{\prime}=\frac{\left(R_{t_{1}}-R_{t_{2}}\right)}{\frac{1}{2}\left(R_{t_{1}}-R_{t_{2}}\right)\left(t_{2}-t_{1}\right)} .
$$

(b) From the mean daily output of ${ }^{14} \mathrm{CO}_{2}$, collected for several days between day 20 and day 30 divided by the mean amount of radioactivity remaining in the body.

The rate of amino acid loss (endogenous loss) was calculated as: fractional rate of loss $\times$ total amino acid content of the body.

\section{RESULTS}

Since the design of the two experiments was rather different, the results will be considered separately.

\section{Expt I}

The body-weight remained constant throughout the $30 \mathrm{~d}$ on the low-protein diet. The cumulative excretion and specific radioactivity (SR) of ${ }^{14} \mathrm{CO}_{2}$ after intragastric injection of the labelled amino acids without carrier are shown in Figs. I and 2. The cumulative loss was higher for lysine (about $12 \%$ of the dose excreted in $3 \mathrm{~h}$ ) than for leucine (about $8 \%$ excreted in $3 \mathrm{~h}$ ). These results for lysine agree with those previously obtained in rats given protein-free diets (Neale, 1971).

The highest SR of $\mathrm{CO}_{2}$ was found at $\mathrm{I} h$ for both amino acids. If the fall-off is considered to be exponential, the half-life was approximately $\mathrm{I} \cdot 5 \mathrm{~h}$.

The partition of ${ }^{14} \mathrm{C}$ radioactivity in tissues between the free and protein-bound fractions was measured in a number of animals. At $3 \mathrm{~h}$ after administration of $\left[{ }^{14} \mathrm{C}\right]$ leucine, $97.7 \%$ of the radioactivity in liver and $93.7 \%$ of that in muscle was recovered in the protein fraction. With lysine the uptake into protein at $3 \mathrm{~h}$ was less, $92.4 \%$ of the radioactivity in liver, and $75.9 \%$ of that in muscle was protein-bound. At all other time-intervals the radioactivity in all tissues was completely confined to the protein and was not detectable in the free amino acid fraction.

The SR of the mixed, soluble tissue proteins at different intervals after administra- 


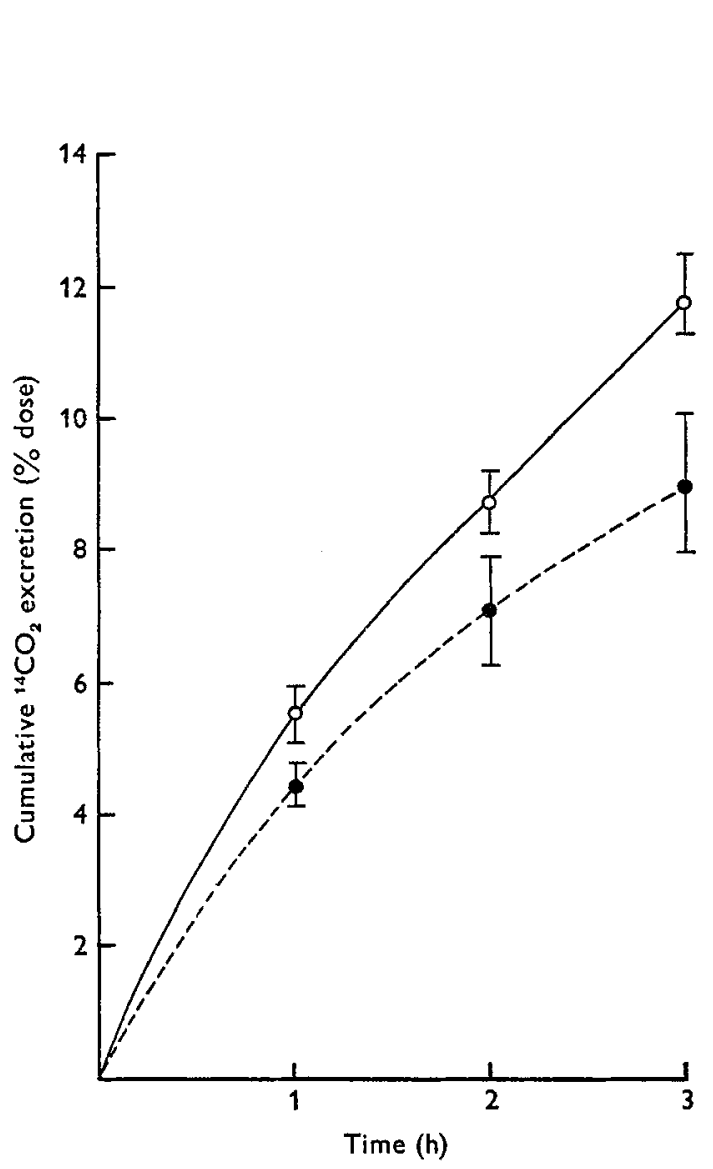

Fig. I

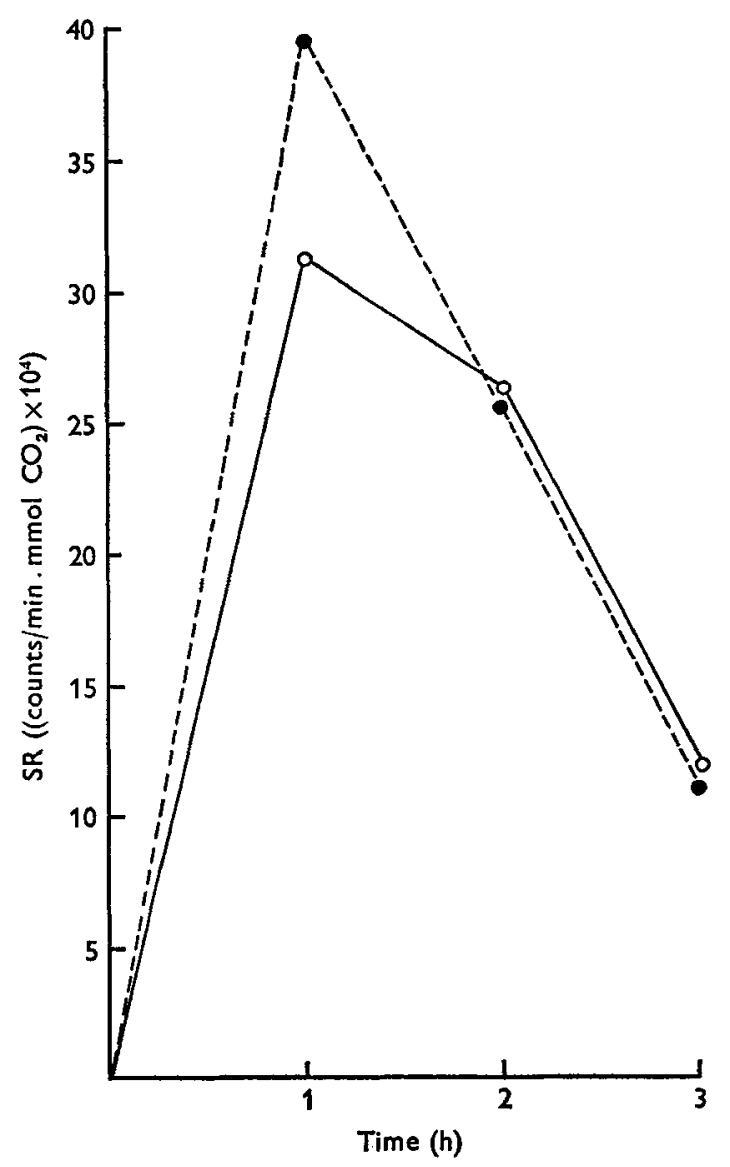

Fig. 2

Fig. I. Expt I. Cumulative ${ }^{14} \mathrm{CO}_{2}$ excretion after intragastric administration of $\left[{ }^{14} \mathrm{C}\right]$ leucine or $\left[{ }^{14} \mathrm{C}\right]$ lysine in rats given a low-protein diet; $\mathrm{O}-\mathrm{O},\left[{ }^{14} \mathrm{C}\right]$ lysine; $---0,\left[{ }^{14} \mathrm{C}\right]$ leucine.

Fig. 2. Expt I. $\mathrm{CO}_{2}$ specific radioactivity (SR) after intragastric administration of $\left[{ }^{14} \mathrm{C}\right]$ leucine or $\left[{ }^{14} \mathrm{C}\right]$ lysine in rats given a low-protein diet; $\mathrm{O}-\mathrm{O},\left[{ }^{14} \mathrm{C}\right]$ lysine; $-\cdots,\left[{ }^{14} \mathrm{C}\right]$ leucine.

tion of the isotope is shown in Table 2. With both leucine and lysine the SR of liver protein was very high initially, but fell rapidly in the first $\mathrm{I}_{5} \mathrm{~d}$. By contrast, the SR of muscle was higher at $\mathrm{r}_{5} \mathrm{~d}$ than at $3 \mathrm{~h}$ after administration of the labelled amino acid.

At $20 \mathrm{~d}$ with both amino acids the SR was approximately the same in liver, viscera and muscle; in skin it was about half that found in the other tissues.

Table 3 shows the distribution of radioactivity at different intervals after labelled amino acid + carrier had been given. The over-all loss was much greater in the first than in the second $\mathrm{I}_{5} \mathrm{~d}$ period. As would be expected, during the first $\mathrm{I}_{5} \mathrm{~d}$ the loss was more rapid from liver and viscera than from carcass and skin.

Total recovery at $3 \mathrm{~h}$ for both lysine and leucine was higher than the difference calculated from that lost as ${ }^{14} \mathrm{CO}_{2}$ (Fig. $\mathrm{I}$ ) in $3 \mathrm{~h}$. This was because the figures and tables relate to different rats, and also carrier amino acid was not included in the experiments 
Table 2. Expt I. Specific radioactivity $(S R)$ of liver, muscle, visceral and skin proteins of male hooded rats given a low-protein diet $(45 \mathrm{~g}$ casein $/ \mathrm{kg}), 0,15,20$ and $30 \mathrm{~d}$ after intragastric administration of $\left[{ }^{14} \mathrm{C}\right]$ leucine or $\left[{ }^{14} \mathrm{C}\right]$ lysine

(Mean values with their standard errors; no. of rats in parentheses)

$\mathrm{SR}$ of tissue proteins (counts/min per $\mathrm{mg}$ protein)

\begin{tabular}{|c|c|c|c|c|c|c|c|c|}
\hline \multirow{2}{*}{$\begin{array}{l}\text { Time } \\
\text { (d) }\end{array}$} & \multicolumn{2}{|c|}{ Liver } & \multicolumn{2}{|c|}{ Muscle } & \multicolumn{2}{|c|}{ Viscera } & \multicolumn{2}{|c|}{ Skin } \\
\hline & Mean & SE & Mean & $\mathrm{SE}$ & Mean & $\mathrm{SE}$ & Mean & SL \\
\hline & \multicolumn{8}{|c|}{ Leucine } \\
\hline 0 & $355^{\circ}$ & $634(3)$ & 380 & II (3) & - & 一 & - & - \\
\hline I 5 & 554 & I $5(2)$ & 431 & $14(2)$ & 407 & I $5(2)$ & 210 & $2 \times(2)$ \\
\hline 20 & $3^{6} 3$ & $43(2)$ & 334 & $4 I(2)$ & 319 & $27(2)$ & 194 & $29(2)$ \\
\hline \multirow[t]{2}{*}{30} & 279 & $56(2)$ & $26_{3}$ & $22(2)$ & $26 I$ & $43(2)$ & I3I & $2(2)$ \\
\hline & \multicolumn{8}{|c|}{ Lysine } \\
\hline$\circ$ & 208 I & 233 (3) & 306 & IO (3) & - & 一 & - & - \\
\hline 15 & 513 & I 6 (3) & 371 & $24(3)$ & 407 & $23(3)$ & I 45 & $5(3)$ \\
\hline 20 & 338 & $3(2)$ & 372 & $5 I(2)$ & 339 & $64(2)$ & 182 & $20(2)$ \\
\hline 30 & 249 & $9(2)$ & 309 & $27(2)$ & 266 & $20(2)$ & 115 & I (2) \\
\hline
\end{tabular}

Table 3. Expt 1 . Percentage of the initial dose of ${ }^{14} \mathrm{C}$ retained in different tissues of male hooded rats given a low-protein diet (45 $\mathrm{g}$ casein $/ \mathrm{kg}), 3 \mathrm{~h}$ and $\mathrm{I} 5,20$ and $30 \mathrm{~d}$ after intragastric administration of $\left[{ }^{14} \mathrm{C}\right]$ leucine or $\left[{ }^{14} \mathrm{C}\right]$ lysine

(Mean values with their standard errors, no. of rats in parentheses)

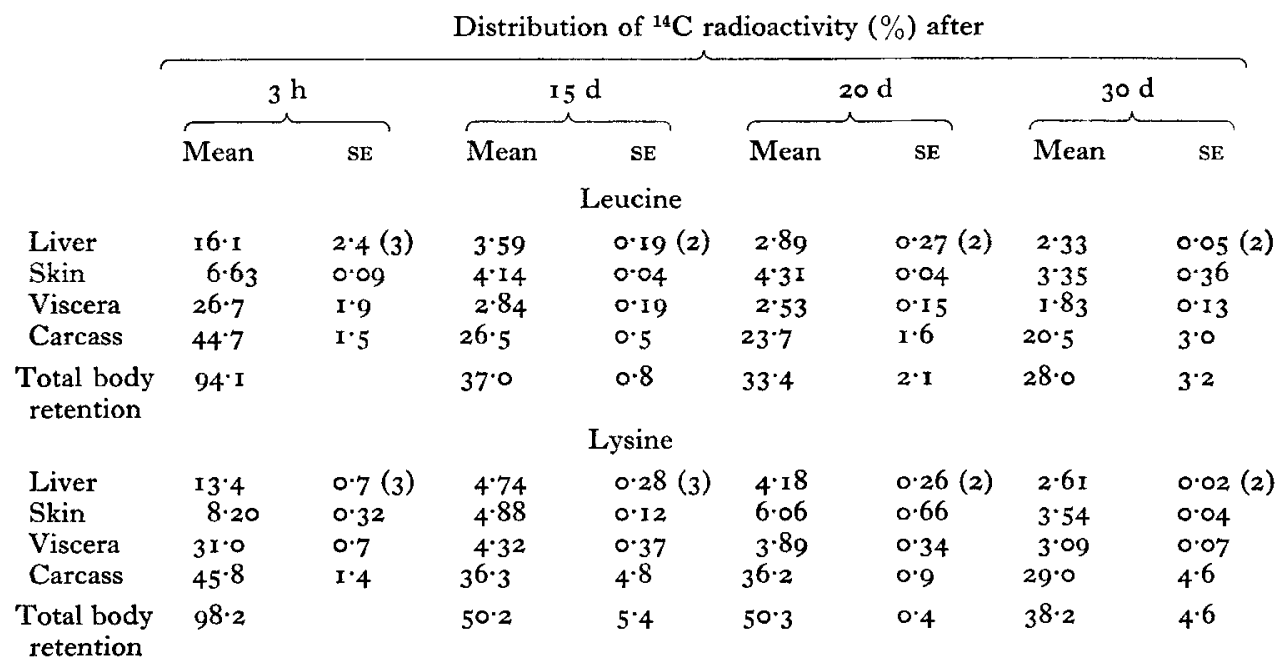

in Figs $\mathrm{I}$ and 2, as it was in Table 3: the presence of carrier amino acid appears to decrease the initial loss of ${ }^{14} \mathrm{C}$-labelled amino acid as ${ }^{14} \mathrm{CO}_{2}$.

Table 4 shows the fractional rates of loss of radioactivity for the different tissues and for the whole body. It is certainly erroneous to calculate the rates of loss during the first $\mathrm{I} 5 \mathrm{~d}$ as if they were exponential. These values have only been calculated so that comparisons can be made between the two amino acids. Between day 20 and 
Table 4. Expt I. Fractional rates of loss $(\% / d)$ of isotope from different tissues and from the whole body of male hooded rats after intragastric administration of $\left[{ }^{14} \mathrm{C}\right]$ leucine or $\left[{ }^{14} \mathrm{C}\right]$ lysine

\begin{tabular}{|c|c|c|c|c|}
\hline & \multicolumn{2}{|c|}{ Days $0-15$} & \multicolumn{2}{|c|}{ Days 20-30 } \\
\hline & Leucine & Lysine & Leucine & Lysine \\
\hline Liver & 15.0 & 10.4 & $2 \cdot I$ & $4 \cdot 7$ \\
\hline Skin & 477 & $5 \cdot 2$ & $2 \cdot 5$ & $5 \cdot 3$ \\
\hline Viscera & $22: 4$ & $19 \% 7$ & $3 \cdot 2$ & $2 \cdot 3$ \\
\hline Carcass & $5 \cdot 2$ & $2 \cdot 3$ & I. 5 & $2 \cdot 3$ \\
\hline $\begin{array}{l}\text { Whole } \\
\text { body }\end{array}$ & $9 \cdot 3$ & $6 \cdot 7$ & $I \cdot 75$ & $2 \cdot 5$ \\
\hline
\end{tabular}

Table 5. Expt I. Total leucine or lysine content of whole body ( $\mathrm{mg} / \mathrm{I} 00 \mathrm{~g})$, fractional rate of amino acid loss $(\% / d)$ and calculated absolute rate of amino acid loss ( $m g / d$ per $100 \mathrm{~g}$ rat)

\begin{tabular}{|c|c|c|c|}
\hline & $\begin{array}{c}\text { Amino acid } \\
\text { content } \\
\text { of body }\end{array}$ & $\begin{array}{c}\text { Fractional } \\
\text { rate } \\
\text { of loss }\end{array}$ & $\begin{array}{c}\text { Absolute } \\
\text { rate } \\
\text { of loss }\end{array}$ \\
\hline Leucine & 970 & $I \cdot 75$ & $x 7 \cdot 0$ \\
\hline Lysine & IOI 5 & $2 \cdot 5$ & $25 \cdot 4$ \\
\hline
\end{tabular}

day 30 it is more reasonable to regard the loss as exponential. The rate of loss for the carcass determines that for the whole body, because at this stage it contains by far the largest proportion of the isotope retained.

Table 5 shows the measured amounts of leucine and lysine/ $100 \mathrm{~g}$ rat. The total protein content of the rats was not measured, but if it is assumed to be $20 \mathrm{~g}$ for a $100 \mathrm{~g}$ rat, then the average leucine content of the protein would be $4.6 \%$, and that of lysine $5.2 \%$. These values are somewhat lower than those found in liver and muscle (Mitchell, 1959), presumably because of dilution of skin and carcass by collagen.

The absolute rates of amino acid loss are shown in Table 5. These are obtained by multiplying the total amino acid content and the fractional rates of loss for the whole body (Table 4).

Although the body-weights of these rats remained constant over the experimental period, one cannot interpret these rates of loss as representing the amino acid requirement, because there was no reason to suppose that either lysine or leucine was limiting in the diet. Therefore a second series of experiments was done in which, after an initial period of $\mathrm{I}_{5} \mathrm{~d}$ to allow for distribution of isotope throughout the tissues, the rats were given either a PF diet or a diet containing no lysine or leucine.

\section{Expt 2}

Expt $2 A$. Between day 20 and day 30 rats on the PF diet lost $13.2 \%$ of initial bodyweight, while those on the LF diet lost $9.6 \%$.

The specific radioactivities of the tissue proteins are shown in Table 6 . The values were similar to those found in the previous experiment, except that, in the LF group at $20 \mathrm{~d}$, the values for the SR of visceral protein were rather high and variable. This group, however, contained only two rats. 
Table 6. Expt 2 A. Specific radioactivity $(S R)$ of liver, muscle, visceral and skin proteins of male hooded rats at day 20 and day 30 after intragastric administration of $\left[{ }^{14} C\right]$ lysine, after replacing the low-protein diet with a protein-free $(P F)$ or lysine-free $(L F)$ diet at day I 5

(Mean values with their standard errors, no. of rats in parentheses)

\begin{tabular}{|c|c|c|c|c|c|c|c|c|c|}
\hline \multirow[b]{3}{*}{ Diet } & \multirow{3}{*}{$\begin{array}{l}\text { Time } \\
\text { (d) }\end{array}$} & \multicolumn{8}{|c|}{$\mathrm{SR}$ of tissue proteins (counts/min per mg protein) } \\
\hline & & \multicolumn{2}{|c|}{ Liver } & \multicolumn{2}{|c|}{ Muscle } & \multicolumn{2}{|c|}{ Viscera } & \multicolumn{2}{|c|}{ Skin } \\
\hline & & Mean & $\widehat{\mathrm{SE}}$ & Mean & $\mathrm{SE}$ & Mean & SE & Mean & SE \\
\hline LF & 20 & 271 & $33(2)$ & 298 & IO (2) & 364 & II $6(2)$ & 209 & $32(2)$ \\
\hline LF & 30 & 239 & $2 I(5)$ & 248 & II (5) & 233 & $30(5)$ & I 71 & I5（5） \\
\hline$\overline{\mathrm{PF}}$ & 20 & 289 & $36(2)$ & 282 & $44(2)$ & 297 & $14(2)$ & 206 & $36(2)$ \\
\hline $\mathrm{PF}$ & 30 & 228 & I6 (5) & 247 & $5(5)$ & 246 & I $8(5)$ & 149 & I I (5) \\
\hline
\end{tabular}

Table 7. Expt 2 A. Percentage of initial dose of ${ }^{14} \mathrm{C}$ retained in different tissues of male hooded rats 20 and 30 d after intragastric administration of $\left[{ }^{14} C\right]$ lysine after replacing the low-protein diet with a protein-free $(P F)$ or a lysine-free $(L F)$ diet at day $\mathrm{I} 5$

(Mean values with their standard errors, no. of rats in parentheses)

\begin{tabular}{|c|c|c|c|c|c|c|c|c|}
\hline \multirow[b]{4}{*}{ Tissue } & \multicolumn{6}{|c|}{ Distribution of ${ }^{14} \mathrm{C}$ radioactivity $(\%)$ after: } & & \\
\hline & \multicolumn{2}{|c|}{$20 \mathrm{~d}$} & \multicolumn{4}{|c|}{$3 \circ \mathrm{d}$} & \multirow{2}{*}{\multicolumn{2}{|c|}{$\begin{array}{l}\text { Fractional } \\
\text { rate of loss } \\
\text { day } 20-30\end{array}$}} \\
\hline & \multirow[b]{2}{*}{ Mean } & \multirow[b]{2}{*}{ SE } & \multicolumn{2}{|c|}{ PF } & \multicolumn{2}{|c|}{ LF } & & \\
\hline & & & Mean & SE & Mean & SE & PF & LF \\
\hline Liver & $3 \cdot 10$ & $14(4)$ & $2 \cdot 24$ & $0.09(5)$ & $2 \cdot 29$ & $0.02(5)$ & $3 \cdot 20$ & 3.00 \\
\hline Skin & $7 \cdot 92$ & 0.27 & 4.95 & 0.28 & 5.25 & 0.15 & 470 & $4 \cdot 10$ \\
\hline Viscera & $3 \cdot 6 \mathrm{r}$ & 0.42 & $2 \cdot 50$ & 0.07 & $2 \cdot 46$ & 0.13 & 3.70 & $3 \cdot 80$ \\
\hline Carcass & 33.9 & $2 \cdot 1$ & $25 \cdot 3$ & 0.5 & $26 \cdot 7$ & $I \cdot 2$ & $2-90$ & 2.40 \\
\hline $\begin{array}{l}\text { Total } \\
\text { body } r\end{array}$ & $\begin{array}{l}48 \cdot 5 \\
\text { ention }\end{array}$ & $2 \cdot 2$ & $35^{\circ} \circ$ & 0.7 & $36 \cdot 7$ & $I \cdot 4$ & $3 \cdot 24$ & $2 \cdot 80$ \\
\hline
\end{tabular}

Table 7 shows the distribution of radioactivity at 20 and $30 \mathrm{~d}$, and the fractional rates of loss from the different tissues and whole body. These rates are in general higher with the PF than with the LF diet, and somewhat higher than those found with the low-protein diet (Table 4). The rapid rate of loss from skin is remarkable, and fits in with the observation of Waterlow and Stephen (1966) that in the rat given a protein-free diet, more protein is lost from skin than from any other tissue.

The corrected SR of respiratory $\mathrm{CO}_{2}$ was measured daily between day 20 and day 30 (Fig. 3). The change from low-protein to PF diet was followed by a small and transient fall in the SR of $\mathrm{CO}_{2}$, which showed considerable fluctuations from day to day. By contrast, the change to the LF diet was followed by a very marked fall in the SR of respiratory $\mathrm{CO}_{2}$, to one-third of its previous level, and this low level was maintained for the rest of the experimental period.

It was difficult to reconcile the very great difference in SR of respiratory $\mathrm{CO}_{2}$ in the two groups with the fact that the rates of loss of radioactivity from the whole 


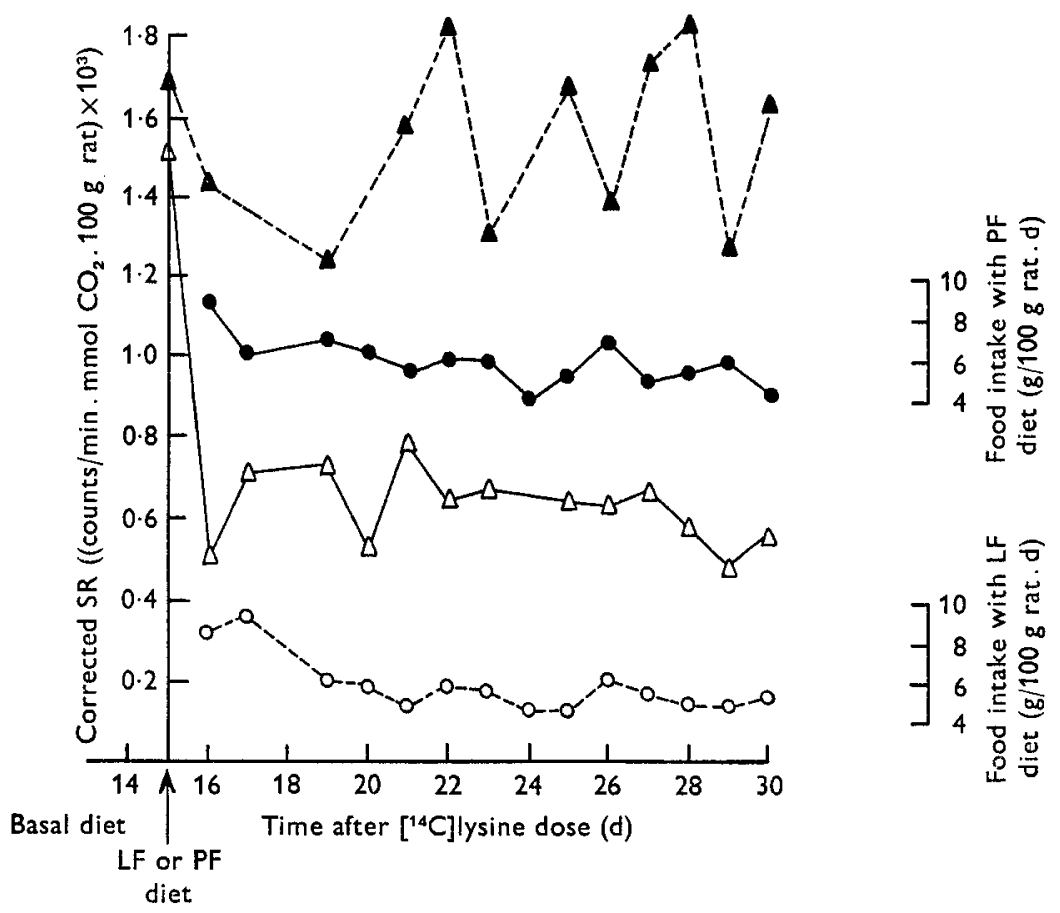

Fig. 3. $\mathrm{CO}_{2}$ specific radioactivity (SR) and food intake $\mathrm{I}_{5} \mathrm{~d}$ after intragastric administration of $\left.{ }^{[1} \mathrm{C}\right]$ lysine, after changing from a basal (low-protein) to a lysine-free (LF) or protein-free (PF) diet; $\triangle \cdots \Delta, \mathrm{CO}_{2}$ SR with the PF diet; $\triangle \longrightarrow \triangle, \mathrm{CO}_{2}$ SR with the LF diet; $\mathrm{O}-\mathrm{O}$, food intake with PF diet; - - - , food intake with LF diet. SR was corrected for body-weight by dividing the measured $\mathrm{CO}_{2}$ specific activity by the body-weight of the rat at the time of collection of $\mathrm{CO}_{2}$.

body differed by only $15 \%$ (Table 7 ). Therefore a further experiment was done in which the total loss of ${ }^{14} \mathrm{C}$ was measured in $\mathrm{CO}_{2}$ and in urine.

Expt $2 B$. In this experiment weanling rats weighing $40 \mathrm{~g}$ were given the basal diet in which the $\mathrm{N}$ was derived from amino acids (equivalent to $45 \mathrm{~g}$ casein/diet $\mathrm{kg}$ ). After $15 \mathrm{~d}$ the basal diet was replaced either by a LF or a PF diet. Respiratory $\mathrm{CO}_{2}$ was collected for $2 \mathrm{~h}$ on each of $8 \mathrm{~d}$ between day $2 \mathrm{I}$ and day 30 . Some collections of $\mathrm{CO}_{2}$ were made during the night. It was found that the hourly output in the night was not significantly different from that in the day. Therefore the $24 \mathrm{~h}$ output was calculated from the $2 \mathrm{~h}$ collections made each morning. Urine collections were also made during the period between day 20 and day 30 and these showed that $1-2 \%$ of the dose of ${ }^{14} \mathrm{C}$ excreted as ${ }^{14} \mathrm{CO}_{2}$ was excreted in the urine. This is negligible compared with that excreted as $\mathrm{CO}_{2}$. There was no difference in the ${ }^{14} \mathrm{C}$ radioactivity excreted in urine between the PF or LF groups although the total $24 \mathrm{~h}$ urine volume was substantially less in the PF than LF groups. Between day 25 and day 30 the mean volume was $9 \mathrm{ml}$ for LF group and $3 \mathrm{ml}$ for the PF group. No carcass analyses were done in this experiment.

The results for respiratory $\mathrm{CO}_{2}$ are shown in Table 8 . The total daily output of $\mathrm{CO}_{2}$ was $\mathrm{I} 8 \%$ greater for the LF than that for the PF group. At the same time the 


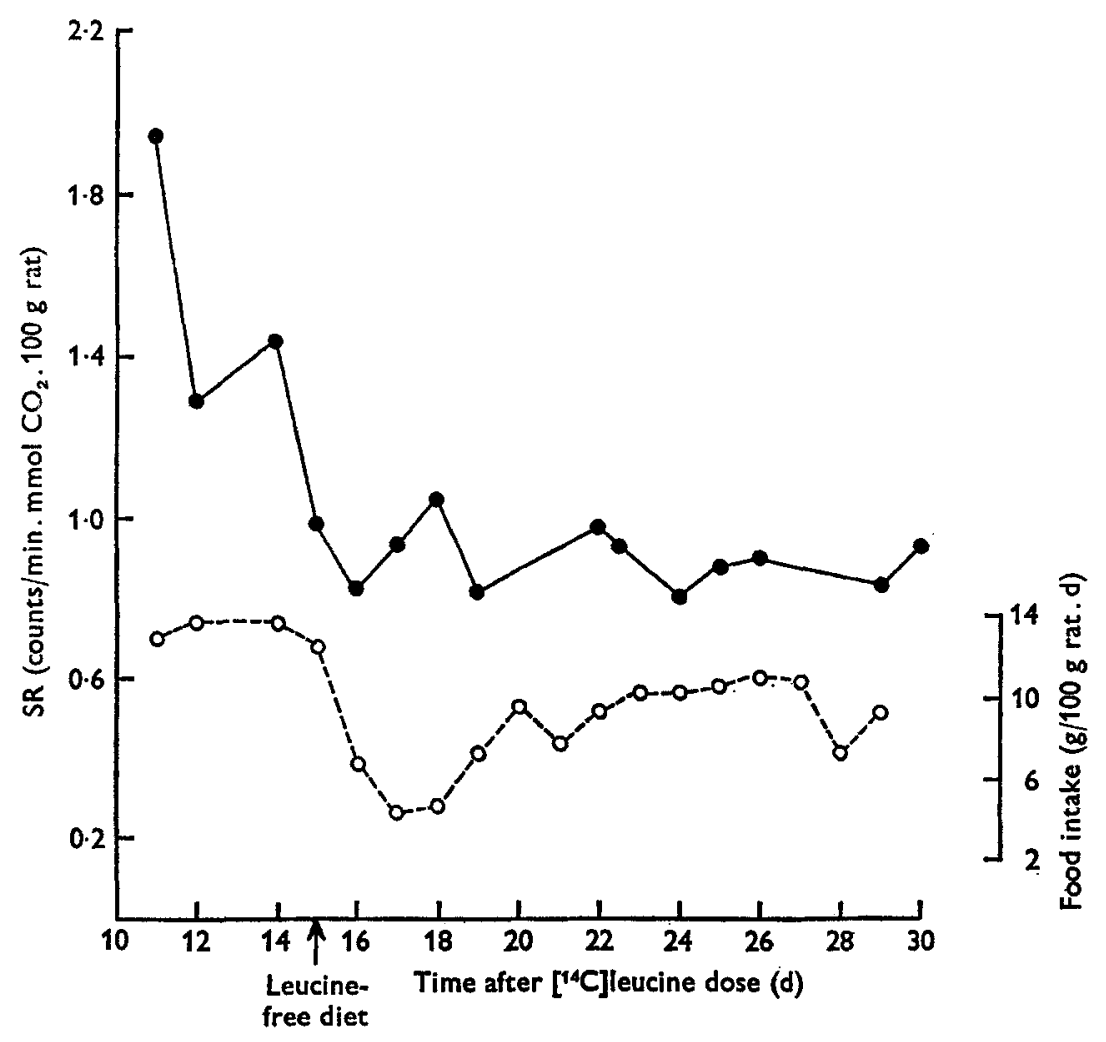

Fig. 4. $\mathrm{CO}_{2}$ specific radioactivity (SR) and food intake ro $\mathrm{d}$ after intragastric administration of [ [ $\left.{ }^{14} \mathrm{C}\right]$ leucine and replacement of the basal diet at day 15 with a leucine-free diet; $\mathrm{CO}_{2}$ SR with leucine-free diet; $\mathrm{O}-\mathrm{O}$, food intake with leucine-free diet.

Table 10. Expt 2 C. Total $\mathrm{CO}_{2}$ excretion and ${ }^{14} \mathrm{CO}_{2}$ radioactivity lost during 8 d between day 20 and day 30 after intragastric administration of $\left[{ }^{14} \mathrm{C}\right]$ leucine $(5 \mu \mathrm{Ci})$ to weanling male Sprague-Dawley rats given a leucine-free diet at day ${ }_{1} 5$

(Mean values with their standard errors; no. of rats in parentheses)

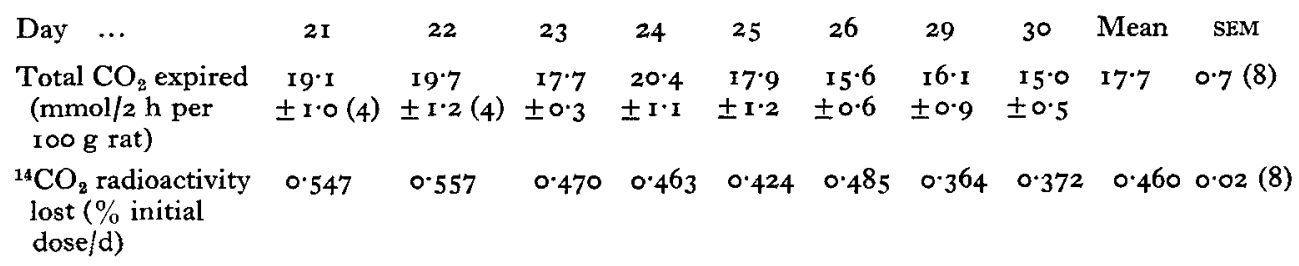

a leucine-free diet. No comparison was made with a PF diet. The results are shown in Fig. 4 and Table 10. The SR of expired $\mathrm{CO}_{2}$ fell sharply towards the end of the period on the basal diet, but, in contrast to the findings with LF group (Fig. 3 ), there was no further fall after the rats were changed to the leucine-free diet. The output of ${ }^{14} \mathrm{CO}_{2}$ was much less than in the rats given the LF diet (Table 8). If it is 
assumed from the results in Table 3 that the mean retention of radioactivity between days 20 and 30 was $3 \mathrm{I} \%$ of the initial dose, then the fractional rate of loss of ${ }^{14} \mathrm{C}$ can be calculated as before. This result is also shown in Table 9 .

\section{DISCUSSION}

The idea behind this work is the simple one that the maintenance requirement of an amino acid is the net rate of loss from the body which has to be replaced, i.e. the endogenous loss. This loss occurs essentially by oxidation; loss in the urine is very small and we have neglected it.

The oxidative loss represents the irreversible destruction of the carbon chains of the essential amino acids. The first irreversible step is decarboxylation of the keto-acid formed by transamination. The remainder of the carbon chain may then be completely oxidized to $\mathrm{CO}_{2}$ or, in the instance of both leucine and lysine, converted to fat (Krebs, I964).

In this discussion it is assumed that oxidation of the carbon chains of the labelled amino acids is complete and that no radioactivity is retained in the body in the form of fat. Some in vivo results of Neale (unpublished observations) support this assumption. Adult rats were given an equal intragastric dose of either $\left[\mathrm{U}-{ }^{14} \mathrm{C}\right]$ - or $\left[\mathrm{I}^{14} \mathrm{C}\right] \mathrm{leu}-$ cine, and after $30 \mathrm{~d}$ on a low-protein diet were killed and the total body fat extracted. The fat was $9.5 \%$ final body-weight. The ${ }^{14} \mathrm{C}$ radioactivity in the fat was less than $0.1 \%$ initial dose for $\left[{ }^{\mathrm{I}}-{ }^{14} \mathrm{C}\right]$ leucine and $\mathrm{I} \cdot 07 \%$ initial dose for $\left[\mathrm{U}-{ }^{14} \mathrm{C}\right]$ leucine. Most of the $\left[\mathrm{U}_{-}{ }^{14} \mathrm{C}\right]$ leucine given was therefore oxidized or incorporated into protein and not retained as storage fat. Odyssey \& Goldberg (1972) also provide evidence of complete oxidation of $\left[\mathrm{U}^{14} \mathrm{C}\right]$ leucine by various samples of rat muscle in vitro. If this assumption is correct the rate of loss of labelled amino acid can be determined either by analysis of the whole body at different intervals of time, as in Expt I, or by measuring the output of ${ }^{14} \mathrm{CO}_{2}$, as in Expt 2. If the assumption is wrong, both methods will underestimate the endogenous loss, as defined above. Carcass analysis will underestimate it because the tissues were not fat-extracted before measurements were made, and so any ${ }^{14} \mathrm{C}$ in fat will be estimated with ${ }^{14} \mathrm{C}$ retained in protein. Measurement of ${ }^{14} \mathrm{CO}_{2}$ output will underestimate it if only part of the ${ }^{14} \mathrm{C}$ of the carbon chains is excreted as $\mathrm{CO}_{2}$.

The endogenous rate of amino acid loss can be determined from the rate of loss of isotope only if all the amino acid being oxidized has the same specific radioactivity. In theory, with many different pools of protein turning over at different rates, this condition can never be reached. In practice it was almost reached between days 20 and 30 except for the proteins in skin.

Both methods of measuring the rate of loss have their disadvantages. To determine the change in the amount of radioactivity retained in the body it is necessary to make measurements on different groups of rats at different intervals of time. This inevitably introduces uncertainties. Moreover, the loss is the difference between two much larger values, and therefore cannot be measured very precisely. We had hoped that it might be possible to measure the rate of loss more accurately in each individual rat 
from the rate of fall in amount or SR of expired ${ }^{14} \mathrm{CO}_{2}$. However, as Figs 3 and 4 and Tables 8 and io show, these values fluctuated from day to day over a rather wide range, no doubt because of variations in physical activity and food intake. Therefore it was necessary to calculate the rate of loss from the average excretion of ${ }^{14} \mathrm{CO}_{2}$ expressed as a fraction of the dose remaining in the body over the period of observation. In hind-sight, it is unfortunate that direct measurements of the radioactivity retained were not made in all experiments. These various sources of error must be borne in mind in the analysis of the results which follows.

With leucine there was reasonably close agreement, probably within experimental error, between the rates of loss obtained by the two methods. The rate was slightly higher in Expt 1, when the rats were just maintaining weight on a low-protein diet, than in Expt 2 when they were on a leucine-free diet. It is possible that even at the maintenance level, economy of amino acids is less efficient than when the intake is zero. This would be analogous to the finding in man that feeding an amount of $\mathrm{N}$ equal to the total obligatory loss is not enough to secure $\mathrm{N}$ balance (FAO/WHO, 1973).

For lysine the position is more complicated. The results obtained from measurements of retained radioactivity in rats given the low-protein diet (Expt 1 ) and the LF $\operatorname{diet}(\operatorname{Expt} 2 \mathrm{~A})$ are in good agreement, giving a rate of loss of $2 \cdot 7-2 \cdot 8 \% / \mathrm{d}$. With the $\mathrm{PF}$ diet the rate of loss was greater, whether measured by loss of radioactivity from the body or by output of ${ }^{14} \mathrm{CO}_{2}$. These rats also lost more weight; it is likely that there are some essential amino acids which are less efficiently conserved than lysine; therefore, with a PF diet there would be more wastage of protein, and hence of lysine, than with a diet in which lysine alone is limiting. The rate of loss calculated from $\mathrm{CO}_{2}$ output in the rats given the LF $\operatorname{diet}($ Expt $2 \mathrm{~B}$ ) was substantially less than that calculated from retained radioactivity (Expt $2 \mathrm{~A}$ ). There is no obvious explanation for this, except that the rats in Expt $2 \mathrm{~B}$ were younger, and perhaps able to conserve lysine more efficiently.

A point of some interest is that the initial loss, between day o and day ${ }_{15}$, of leucine is greater than that of lysine, whereas between day 20 and day 30 the situation is reversed. This may be related to differences in the predominant site of oxidation. There is good evidence that the extent of catabolism of a tracer dose of $\left[{ }^{14} \mathrm{C}\right]$ lysine to ${ }^{14} \mathrm{CO}_{2}$ is closely related to the dietary intake of lysine (Yamashita \& Ashida, I969; Soliman \& Harper, 1971; Wang, Crosby \& Nesheim, 1973). This capacity to adapt is presumably a function of the liver, as it is absent in eviscerated animals (Neale, I972). Moreover, the activity of the key enzyme in the liver which is rate-limiting for lysine oxidation, lysine-ketoglutarate reductase, is markedly affected by the level of dietary lysine intake (Wang \& Nesheim, 1972). Therefore with lysine, adaptation may be shown most clearly during the first few days after administration of the isotope, when a large proportion of it is still contained in the liver and viscera.

Leucine is supposed to be mainly oxidized by muscle (Miller, 1962), although some oxidation does occur in liver (McFarlane \& von Holt, r 969). Sketcher, Fern \& James (1974) have shown that on low-protein diets there is no adaptive fall in activity of the rate-limiting enzyme for leucine oxidation, $\alpha$-ketoisocaproic acid dehydrogenase, in 
liver, whereas there is a very marked fall in the activity of this enzyme in muscle. With leucine, therefore, adaptation would be more clearly shown in the later stages, after administration of the labelled amino acid, when most of it had been taken up by muscle.

It may be of interest to compare the method for measuring the maintenance requirement of an amino acid which we have investigated in these experiments with that of Brookes, Owens \& Garrigus (1972). These authors fed diets containing varying amounts of lysine to young rats. A tracer dose of $\left[{ }^{14} \mathrm{C}\right]$ lysine was given and ${ }^{14} \mathrm{CO}_{2}$ collected for $6 \mathrm{~h}$. The amount of lysine oxidized was calculated as follows: 'at least $95 \%$ of the total ${ }^{14} \mathrm{CO}_{2}$ release expected for a $24 \mathrm{~h}$ period occurred in the first $6 \mathrm{~h}$. Thus a direct estimation of the oxidation of lysine to $\mathrm{CO}_{2}$ can be made for a $6 \mathrm{~h}$ period. Multiplying this estimate by the daily lysine intake adjusts for the total lysine flux through the body and provides a quantitative estimate of the total daily lysine oxidation to $\mathrm{CO}_{2}$.' This appears to suggest that $\mathrm{mg}$ lysine oxidized in $24 \mathrm{~h}=\mathrm{mg}$ lysine intake in $24 \mathrm{~h} \times \%{ }^{14} \mathrm{CO}_{2}$ excreted in $24 \mathrm{~h}$.

This method of calculation appears to us unjustified. It takes no account of the endogenous flux, which amounts to about $250 \mathrm{mg}$ lysine/ $100 \mathrm{~g}$ rat per $\mathrm{d}$ (Waterlow \& Stephen, 1967), and is therefore very much greater than the dietary intake except at the highest levels of lysine supplementation used by Brookes et al. (I972) (200 mg/ rat per $\mathrm{d}$ ). The ${ }^{14} \mathrm{CO}_{2}$ excreted is derived from the oxidation of an indeterminate mixture of endogenous and exogenous lysine. Although it is not stated, the rats in the experiments of Brookes et al. (1972) were presumably not being fed during the period of $\mathrm{CO}_{2}$ collection. Therefore the rate of entry of lysine from the gut is not known, nor can it be certain that there is complete mixing of endogenous and exogenous lysine at the site of oxidation. Thus the calculation of the amount of lysine oxidized is erroneous because the specific radioactivity at the site of oxidation is unknown. The error can be shown from the authors' own results. Subtracting the amount supposed to be oxidized from the amount consumed gives the amount retained. At a daily intake of $47 \mathrm{mg}$ lysine, $46 \mathrm{mg}$ were retained; the corresponding weight gain was $3.3 \mathrm{~g} / \mathrm{d}$, i.e. $14 \mathrm{mg}$ lysine/g weight gain. At a daily intake of $206 \mathrm{mg}$ lysine, $182 \mathrm{mg}$ were retained, with a weight gain of $6.3 \mathrm{~g} / \mathrm{d}$, i.e. $29 \mathrm{mg}$ lysine $/ \mathrm{g}$ weight gain. Since tissue gained would normally contain about $10-12 \mathrm{mg}$ lysine/g, it is clear that at higher levels of intake the amount of lysine oxidized is grossly underestimated.

Nevertheless, this does not invalidate the conclusions which Brookes et al. (1972) draw about lysine requirements. When the estimated amount of lysine oxidized was plotted against intake or when weight gain was plotted against intake, the curves show an inflexion at an intake of $100-120 \mathrm{mg}$ lysine/d. This is taken as the requirement for optimum growth in these rats, and the method could, as the authors say, be used to estimate the maintenance requirement in non-growing rats. The approach is entirely analogous to the estimation of amino acid requirements from the curve of plasma amino acid concentration at different levels of intake (Stockland, Meade \& Melliere, 1970). In this method all that is necessary is that the curve should show an inflexion; the absolute values of the index, whether it be plasma concentration or amount oxidized, are of no importance, so the result is not affected if the values are in error. 
Table I I. Absolute rate of endogenous amino acid loss compared with estimates of maintenance requirement

\begin{tabular}{|c|c|c|}
\hline & Leucine & Lysine \\
\hline Best estimate of fractional rate of loss $(\% / d)$ & $\mathbf{r} \cdot 50^{*}$ & $2 \cdot 44 \dagger$ \\
\hline Total amino acid (mg/roo g rat) & 970 & 1015 \\
\hline Total loss $\left(\mathrm{mg} / \mathrm{kg}^{0.75}\right.$ per d) & 80 & 136 \\
\hline $\begin{array}{l}\text { Maintenance requirementf } \\
\left(\mathrm{mg} / \mathrm{kg}^{0.75} \text { per } \mathrm{d}\right)\end{array}$ & 44 & 34 \\
\hline
\end{tabular}

Finally, we have to compare the estimates obtained in these experiments of the endogenous rates of amino acid loss with previous estimates of the maintenance requirements for lysine and leucine. The best estimates from the various experiments of the rates of endogenous loss are set out in Table I I, and compared with the estimates given by Said \& Hegsted (1970) for the maintenance requirements. There is a very large difference between the results obtained by the two methods, too large to be accounted for by experimental error. There must, therefore, be some fundamental difference which arises from the methods or from the interpretation of the results.

Rats have been maintained on lysine-free diets for considerable periods of time (Bender, 1961), and prevention of coprophagy increases the loss of body-weight in rats on lysine-free diets. Therefore part of the requirement could come from amino acids synthesized by caecal bacteria. This, naturally, would not reduce the endogenous loss of labelled amino acid, but would reduce the maintenance requirement.

The conclusions from the isotopic measurements may not be so unrealistic. Munro (1970) gives the following values for the rat's requirement for maintenance and growth: lysine $420 \mathrm{mg} / \mathrm{kg}^{0 \cdot 75}$, leucine $445 \mathrm{mg} / \mathrm{kg}^{0 \cdot 75}$. The estimate obtained by Brookes et al. (I972) for the lysine requirement is of the same order, but cannot be used for comparison because the weights of the rats are not given. From our results, the total content of both lysine and leucine in the rat's body is approximately ro $\mathrm{mg} / \mathrm{g}$. If growth is occurring at the rate of $5 \mathrm{~g} / \mathrm{ro0} \mathrm{g}$ per d, from Munro's values, the growth requirement for each amino acid of a rat weighing $100 \mathrm{~g}$ would be approximately $50 \mathrm{mg} / \mathrm{d}$, or $282 \mathrm{mg} / \mathrm{kg}^{0.75}$. Subtracting this from Munro's total requirement gives a maintenance requirement for lysine of ${ }^{1} 37 \mathrm{mg} / \mathrm{kg}^{0 \cdot 75}$, and for leucine of $\mathrm{I} 63 \mathrm{mg} / \mathrm{kg}^{0 \cdot 75}$. These are even greater than our estimates.

The isotopic method used in these experiments presented more difficulties than had been anticipated. Neither the low-protein diet (Expt $\mathrm{r}$ ) nor the lysine- or leucine-free diets (Expt 2) provided the ideal conditions for measuring the maintenance requirement. In the former instance, the intake of both amino acids was probably greater than the maintenance requirement, so that the loss was not strictly endogenous. In the latter instance there was a loss of body-weight, and if this was accounted for partly by loss of tissue protein, then by definition maintenance was not achieved. Thus with this method there is a circular situation: to determine the maintenance require- 
ment accurately it is necessary to provide the animals with exactly the amounts of amino acid needed for maintenance. Perhaps, however, this criticism is not as serious as it seems, since the rates of amino acid loss were not very different under the two different dietary conditions. Clearly further work is needed to resolve the problems raised by these experiments.

Part of this work was done while RJN was a member of the MRC External Staff at the Department of Human Nutrition, London School of Hygiene and Tropical Medicine. We thank Professor D. Lewis of the Department of Applied Biochemistry and Nutrition, Nottingham University School of Agriculture for facilities to carry out part of this work and Miss T. Koripamo for help with some of the experiments. We are grateful to Mr P. Broadbent for the amino acid analyses.

\section{REFERENCFS}

Bender, A. E. (r96r). Meeting Protein Needs. Washington, DC: National Academy of Science-National Research Council.

Brookes, I. M., Owens, F. N. \& Garrigus, U. S. (1972). F. Nutr. 102, 27.

FAO/WHO (1973). Tech. Rep. Ser. Wld Hlth Org. no. 522.

Garlick, P., Millward, D. J. \& Waterlow, J. C. (I974). Physiol. Rev. (In the Press.)

Krebs, H. A. (1964). In Mammalian Protein Metabolism Vol. I, p. I25 [H. N. Munro and J. B. Allison, editors]. New York and London: Academic Press.

McFarlane, I. G. \& von Holt, C. (I969). Biochem. F. III, 557.

Miller, L. L. (1962). In Amino Acid Pools p. 708 [J. T. Holden, editor]. Amsterdam: Elsevier.

Mitchell, H. H. (1959). In Protein and Amino Acid Nutrition p. 24 [A. A. Albanese, editor]. New York: Academic Press.

Moore, S. \& Stein, W. H. (1948). F. biol. Chem. 176, 367.

Munro, H. N. (editor) (r970). In Mammalian Protein Metabolism Vol, 4, p. 302. New York: Academic Press.

Neale, R. J. (197I). Nature New Biol. 23I, I 7 .

Neale, R. J. (1972). Biochim. biophys. Acta 273, 80.

Neale, R. J. \& Waterlow, J. C. (1974). Br. Y. Nutr. 32, I 1.

Neuberger, A. \& Webster, T. A. (1945). Biochem. F. 39, 200.

Odyssey, R. \& Goldberg, A. L. (1972). Am. F. Physiol. 223, I 376.

Payne, P. R. \& Stewart, R. J. C. (1972). Lab. Anim. 6, I35.

Rao, P. B. R., Metta, V. C. \& Johnson, B. C. (1959). J. Nutr. 69, 387.

Said, A. K. \& Hegsted, D. M. (1970). F. Nutr. roo, I363.

Sketcher, R. D., Fern, E. B. \& James, W. P. T. (I974). Br. F. Nutr. 3I, 333.

Smith, E. B. \& Johnson, B. C. (1967). Br. F. Nutr. 21, 17.

Soliman, A. \& Harper, A. E. (1971). Biochim. biophys. Acta 244, 146.

Stockland, W. L., Meade, R. J. \& Melliere, A. L. ( I970). F. Nutr. Io0, 925.

Wang, S.-H. \& Nesheim, M. C. (1 972). F. Nutr. ro2, 583 .

Wang, S.-H., Crosby, L. O. \& Nesheim, M. C. (1973). F. Nutr. 1o3, 384 .

Waterlow, J. C. \& Stephen, J. M. L. (1966). Br. F. Nutr. 20, 46r.

Waterlow, J. C. \& Stephen, J. M. L. (r967). Clin. Sci. 33, 489.

Yamashita, K. \& Ashida, K. (1969). F. Nutr. 99, 267.

Zimmerman, R. A. \& Scott, H. M. (1965). F. Nutr. 87, I3. 